\title{
COMMUNITY ATTITUDES TOWARDS THE MENTALLY ILL \\ IN SERBIA
}

Stefan Jerotić ${ }^{1}$

Sara Paravina ${ }^{2}$

Andelija Nikčević ${ }^{3}$

Gordana Mandić Gajić3,

Željko Špiric ${ }^{3,4}$

Nadja P. Marićc ${ }^{1,2}$

1 Clinic for Psychiatry,

Clinical Center of Serbia,

Belgrade, Serbia

2 Faculty of Medicine,

University of Belgrade,

Belgrade, Serbia

3 Faculty of Medicine,

University of Defense,

Belgrade, Serbia

4 Clinic for Psychiatry,

Medical Military Academy,

Belgrade, Serbia

UDK: 616.89-008.47:617.7

doi: 10.5937/engrami1902050J

\section{Summary}

Introduction. Integration of the mentally ill into the community is one of the essential objectives of social rehabilitation. Deinstitutionalization is one of the central points of contemporary mental health reforms across the world. The acceptance of people with mental health problems in the general population is an important factor in determining the success of implementing deinstitutionalization strategies. Furthermore, medical students during their education attain knowledge about mental health problems as standard part of their curriculum. Quantifying the outlook towards people with mental health problems in future doctors is an important determinant of prospective community-based care.

Aim. Assessment of community attitudes towards the mentally ill in a repre- 
sentative sample of General Population, as well as in future medical doctors in Serbia.

Method. This cross-sectional study involved 1068 Serbian speaking adult subjects: 562 medical students and 506 subjects from the general population. Assessment of attitudes was measured by Community Attitudes Towards the Mentally Ill. Four dimensions of attitudes were extracted: Authoritarianism, Benevolence, Social Restrictiveness and Community Mental Health Ideology.

Results. Medical Students showed more favorable attitudes across all dimensions when compared to the representative sample of General Population. In the General Population, less years of education were associated with higher levels of Authoritarian attitudes towards the mentally ill. Female gender was consistently associated with greater Benevolence, irrespective of group affiliation.

Conclusion. Existing positive attitudes towards the mentally ill in the Serbian community suggest that once legislative proceedings for better integration of the mentally ill in the broader society are initiated, we can expect fast and admirable effects in the community management. Focused educational and anti-stigma interventions targeting the general population should be devised.

\section{Key words:}

deinstitutionalization, social stigma, authoritarianism, beneficence

\section{INTRODUCTION}

One of the greatest challenges for psychiatry and clinical psychology during the last decades is linked to integration of mental health patients into community, as opposed to their institutionalization. Community mental health care has further advanced the endeavors for reducing the burden of psychiatric disorders as it was consistently associated with greater patient satisfaction and the quality of life ${ }^{[1]}$. Thus, deinstitutionalization was one of the central points of mental healthcare reforms applied throughout the Western world ${ }^{[2,3,4]}$.

However, the reform of psychiatric services and mental health care is not easy in countries facing social transition, not only due to economic difficulties, but also due to the resistance and marginalization of psychiatry in the society $^{[5]}$. In Serbia, the national strategy for mental health has been adopted by the government of the Republic of Serbia more than 10 years ago $^{[6]}$, and yet the shift towards the progressive trends of Western world mental healthcare (i.e. community psychiatry) has not been sufficiently advanced.

The organization of mental healthcare in Serbia has many advantages, as well as disadvantages. The main advantages are: a balanced territorial coverage of psychiatric departments in general hospitals, existence of day-hospitals in many clinics, well-educated profession- 
als and a long tradition of psychosocial orientation ${ }^{[7]}$. On the opposite, lack of sufficient cooperation between the psychiatric and the social welfare institutions, lack of rehabilitation and professional orientation services, information systems for monitoring mental disorders and, in particular, lack of community mental healthcare, have been noticed as main disadvantages ${ }^{[7]}$.

Mental health policy is one of the factors that strongly influences the deinstitutionalization process. Another factor are the attitudes towards the mentally ill in a given society. The extent to which the general public accepts patients with mental disorders has an indisputable impact on their quality of life and the success of community-based care ${ }^{[1]}$. In this context, some societal traits are a necessary prerequisite for the support and acceptance of mental health patients in the community, such as affirmative attitudes towards community health ideology and benevolent stances towards the mentally ill. In addition to this, a trusting and stimulating relationship between community mental health care recipients and healthcare professionals ${ }^{[8]}$ could be regarded as a necessary requirement, which is not easy to achieve even in the countries with developed economies and contemporary services. A few years ago, results from the European Study of Epidemiology of Mental Disorders yielded that, when faced with a serious emotional problem, almost a third of all respond- ents believed that professional care was worse than or equal to no help ${ }^{[9]}$.

Usual methods of societal studies to evaluate attitudes towards mental illness and community mental health are population based surveys, relying on one of the best received and validated instruments - Community Attitudes Towards the Mentally Ill (CAMI), developed by Taylor and Dear ${ }^{[10]}$. Studies in various parts of the world have been carried out, involving the general population, professionals, and also medical students samples ${ }^{[1,12]}$, showing both similarities and the differences between the countries. Extensive research has been done using the CAMI scale in both European and non-European societies, particularly showing associations with sociodemographic factors such as gender, age and level of education. For example, Winkler et al. ${ }^{[13]}$ in their analysis of differences between medical doctors and general population in Czech Republic found that stigma was prevalent in both groups, even though medical doctors tended to have more favorable attitudes towards the mentally ill in general. Moreover, researchers in India have found high stigmatizing attitudes in rural populations, but these stances were not associated with gender or level of education, contrary to the previous findings ${ }^{[14]}$. Furthermore, a study done by Song et al. in Taiwan showed negative relationships between age and attitudes toward community health care ${ }^{[15]}$. Thus, 
the associations between demographic/ educational factors and stigmatizing attitudes are not always straightforward.

The aim of the present study was to assess community attitudes towards the mentally ill in a sample of general population, as well as in future medical doctors in Serbia. We hypothesized that medical students would have overall more positive attitudes than the general population and that socio-demographic factors, such as age, gender and years of education would influence the attitudes. The study design was approved by the Medical Ethics Committee of the Military Medical Academy and the Board of Clinic for Psychiatry, University Clinical Center of Serbia (Belgrade). All authors certify responsibility for this article. There were no conflicts of interest. The author(s) received no financial support for the research, authorship, and/or publication of this article.

\section{METHODS}

\section{Sample and procedure}

The sample encompassed 1068 Serbian speaking adult subjects: 562 medical students (26\% currently enrolled in the Military Medical Academy at University of Defense, Serbia and 73.7\% enrolled in the Faculty of Medicine, University of Belgrade), and 506 subjects from the general population. All subjects participated voluntarily and anonymously. The cross-sectional assessment consisted of two phases. In the first phase, students of all six years were recruited directly by their teachers and colleagues. The second phase consisted of allocating additional copies of the poll to students, who then distributed them to the local population in their hometowns (excluding family members). We used "snowball sampling" to collect a type of convenience sample of the general population, having in mind the advantages of such method for our data collection (it allows for studies to take place where otherwise it might be impossible to conduct because of a lack of participants and it helps to discover some characteristics about a population).

\section{The Survey}

Assessment of the sociodemographic data included participants' gender, years of age, years of education, region of residence and current year of study (for medical students).

For the purposes of this investigation, a Serbian translation of Community Attitudes Towards the Mentally Ill - CAMI (developed by Taylor and Dear) was used. The questionnaire has been successfully used in previous studies in our region ${ }^{[16,17]}$ and has shown good measurement reliability in Montenegro and Republic of Srpska (mutually intelligible language varieties in Serbia, Bosnia and Herzegovina, Montenegro and Croatia). 
CAMI scale consisted of 40 questions, answered on a 5-point Likert scale. Participants stated their opinions by responding to statements in the survey in the following manner: 1 - completely disagree, 2 - disagree, 3 - neither agree nor disagree, 4 - agree, 5 - completely agree. Four dimensions of attitudes were extracted: Authoritarianism, Benevolence, Social Restrictiveness and Community Mental Health Ideology. Benevolence refers to a considerate and thoughtful stance in relation to the mentally ill. It describes a tendency towards cordial and comprehensive interaction with psychiatric patients, the need of establishing nearness towards them, thus corresponding to a sympathetic view. Authoritarianism indicates favoring of strict obedience of the mentally ill, without concern for personal opinions and individual freedom of the subject. It describes a view of a mentally ill person as someone inferior who requires coercive handling. Community Mental Health Ideology refers to the orientation of individual commitment to community involvement in the therapeutic process of mental rehabilitation. Social restrictiveness refers to maintaining social distance and considering psychiatric patients as dangerous to the community. Higher total scores on Benevolence and Community Mental Health Ideology subscales indicated more favorable attitudes towards the mentally ill. Higher total scores on Authoritarianism and Social
Restrictiveness subscales illustrated less favorable attitudes towards this population. Range of individual subscale results was 1.0 - 5.0.

\section{Statistical analyses}

All statistical analyses were performed by the SPSS version 20.0 statistical software (Armonk, NY: IMB Corp). After the initial testing for normality (the Shapiro-Wilks test), the data was accordingly analyzed using the appropriate parametric or non-parametric test. Between-group analyses were assessed using chi-square test, Student t-test for independent samples and Mann-Whitney test. Associations between variables were assessed using Pearson and Spearman correlational analysis. Effect sizes were provided where appropriate, and interpreted as follows: Cohen's D - 0.20-0.49 small, 0.50-0.79 medium, $>0.80$ large ${ }^{[18]}$.

\section{RESULTS}

\section{Socio-demographic characteristics}

Sociodemographic characteristics of the study sample are shown in Table 1. Demographic characteristics including gender distribution and mean age of the general population group corresponded with the official population based reports ${ }^{[19]}$.

When comparing the two groups, 
Medical Students were significantly younger and more educated than the General Population group, as expected. In the Medical Students group, there were more female participants (66.5\%). Medical students were evenly distributed by year of study: 1st year ( $\mathrm{n}=94,16.7 \%)$, 2nd year $(\mathrm{n}=99,17.6 \%)$, 3rd year $(\mathrm{n}=95,16.9 \%)$, 4 th year $(n=86,15.3 \%), 5$ th year $(n=96$, $17.1 \%)$, 6th year ( $\mathrm{n}=92,16.4 \%)$. General population sample was evenly distributed by gender ( $52.8 \%$ were females).

\section{Attitudes towards the mentally ill}

Mean levels of Community Attitudes towards the mentally ill are shown in Table 2. Marked differences were observed in attitudes towards the mentally ill between the Medical Students and the General Population group. Medical Students showed more favorable attitudes across all subscales. The most noticeable finding was significantly higher Authoritarian view towards the mentally ill in the General Population ( $\mathrm{p}<0.01$, Cohen's $\mathrm{d}=0.54)$. The rest of the differences between the two groups are given in Table 2 .

\section{Community attitudes towards the mentally ill and years of education / years of age}

When assessing the influence of the sociodemographic factors on attitudes towards the mentally ill in the general population, less years of education were associated with higher levels of Authoritarian attitude $(\mathrm{r}=-0.21, \mathrm{p}<0.01)$, while more years of education were associated with more favorable opinions about Community Psychiatry Ideology $(r=0.16$, $\mathrm{p}<0.01$ ). Years of education were negatively associated with Authoritarianism $(\mathrm{r}=-0.15, \mathrm{p}<0.01)$ in the Medical Students group, while in General Population this

Table 1. Sociodemographic characteristics of the sample

\begin{tabular}{l|c|c|c|c} 
& $\begin{array}{c}\text { Total sample } \\
(\mathbf{n}=1068)\end{array}$ & $\begin{array}{c}\text { General } \\
\text { population } \\
(\mathbf{n}=\mathbf{5 0 6})\end{array}$ & $\begin{array}{c}\text { Medical } \\
\text { students } \\
(\mathbf{n}=562)\end{array}$ & $\mathbf{p}^{\mathbf{1}}$ \\
\hline Age (years) & $29.5 \pm 13.5$ & $38.1 \pm 15.5$ & $21.8 \pm 1.9$ & $0.00^{\mathbf{a}}$ \\
\hline Gender (female, \%) & $641(60.0 \%)$ & $267(52.8 \%)$ & $374(66.5 \%)$ & $0.00^{*}$ \\
\hline Education (years) & $14.6 \pm 2.5$ & $13.9 \pm 2.9$ & $15.3 \pm 1.8$ & $0.00^{*}$ \\
\hline \hline
\end{tabular}

1 GP vs. MS between group differences

a All results were presented as mean $\pm \mathrm{SD}$ ${ }^{*} \mathrm{p}<0.01$ 
was not the case $(\mathrm{r}=0.03, \mathrm{p}=0.49)$. There titudes. The rest of the results are shown were no other significant associations in Table 3.

with other dimensions of community at-

Table 2.

Mean scores and differences in the Community Attitudes Towards the Mentally Ill

\begin{tabular}{|c|c|c|c|c|c|}
\hline & $\begin{array}{c}\text { Total sample } \\
\text { mean } \pm \text { SD }\end{array}$ & $\begin{array}{c}\text { General } \\
\text { population } \\
\text { mean } \pm \text { SD }\end{array}$ & $\begin{array}{c}\text { Medical } \\
\text { students } \\
\text { mean } \pm \text { SD }\end{array}$ & $p^{1}$ & $\begin{array}{l}\text { Cohen's D } \\
\text { (effect size) }\end{array}$ \\
\hline Benevolence & $3.95 \pm 0.56$ & $3.86 \pm 0.60$ & $4.04 \pm 0.51$ & $0.00 *$ & 0.32 \\
\hline Authoritarianism & $2.55 \pm 0.51$ & $2.69 \pm 0.49$ & $2.42 \pm 0.50$ & $0.00 *$ & 0.54 \\
\hline $\begin{array}{l}\text { Community psychiatry } \\
\text { ideology }\end{array}$ & $3.73 \pm 0.57$ & $3.63 \pm 0.56$ & $3.83 \pm 0.57$ & $0.00 *$ & 0.35 \\
\hline $\begin{array}{l}\text { Social restrictiveness } \\
\text { ideology }\end{array}$ & $2.40 \pm 0.58$ & $2.53 \pm 0.56$ & $2.28 \pm 0.58$ & $0.00 *$ & 0.43 \\
\hline
\end{tabular}

1 GP vs. MS between group differences

${ }^{*} \mathrm{p}<0.01$

\section{Figure 1.}

Differences between CAMI scores in General population and Medical Students ${ }^{\star} \mathrm{p}<0.01$

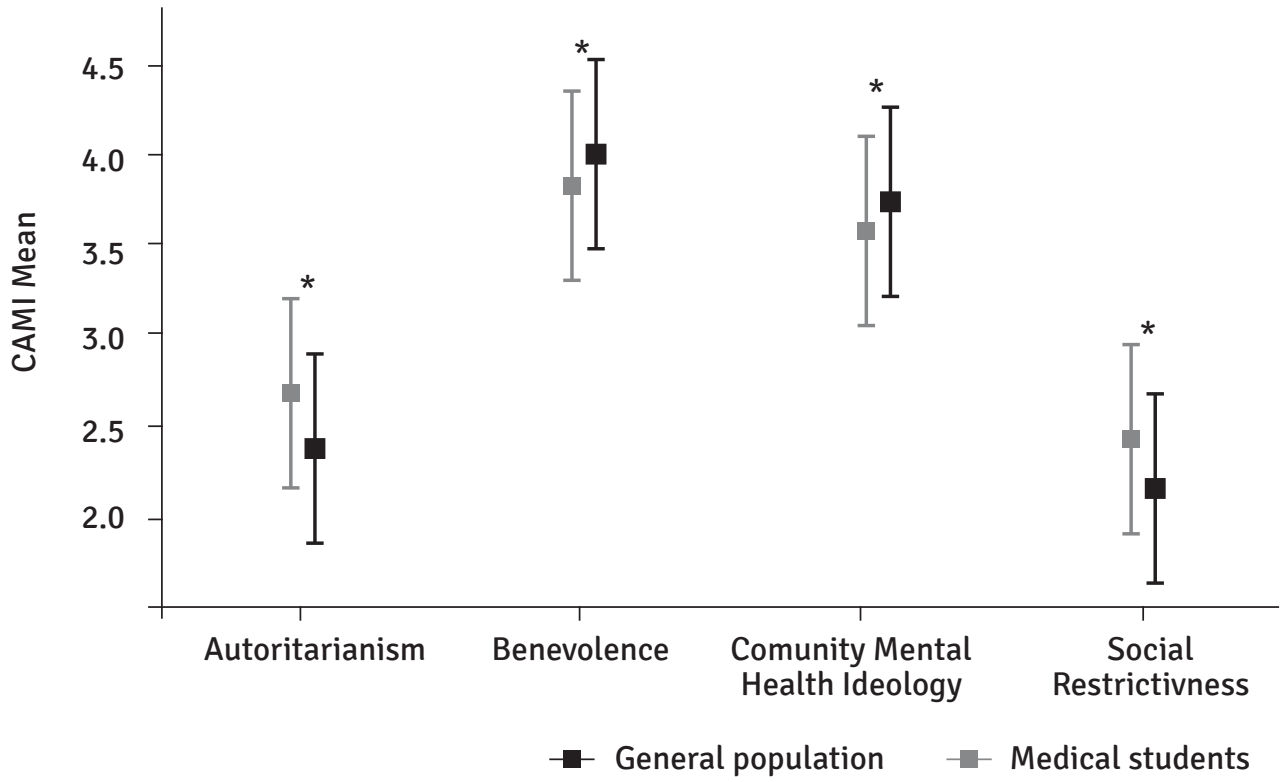


Table 3.

Association of years of education/age with attitudes towards the mentally ill in the general population

\begin{tabular}{l|c|c|c|c}
\multirow{2}{*}{} & \multicolumn{2}{|c|}{ General population } & \multicolumn{2}{c}{ Medical students } \\
\cline { 2 - 5 } & $\begin{array}{c}\text { Years of } \\
\text { education }\end{array}$ & $\begin{array}{c}\text { Years of } \\
\text { age }\end{array}$ & $\begin{array}{c}\text { Years of } \\
\text { education }\end{array}$ & Years of age \\
\hline Authoritarianism & $\begin{array}{c}r=-0.21^{* *} \\
p=0.00\end{array}$ & $\begin{array}{c}r=0.03 \\
p=0.49\end{array}$ & $\begin{array}{c}r=-0.15^{* *} \\
p=0.00\end{array}$ & $\begin{array}{c}r=-0.10^{*} \\
p=0.01\end{array}$ \\
\hline Benevolence & $\begin{aligned} r=-0.01 \\
p=0.70\end{aligned}$ & $\begin{array}{c}r=-0.03 \\
p=0.45\end{array}$ & $\begin{array}{c}r=-0.03 \\
p=0.44\end{array}$ & $\begin{array}{c}r=-0.04 \\
p=0.25\end{array}$ \\
\hline Community psychiatry & $r=0.16^{* *}$ & $r=0.04$ & $r=0.03$ & $r=0.00$ \\
ideology & $p=0.00$ & $p=0.93$ & $p=0.44$ & $p=0.85$ \\
\hline Social restrictiveness & $r=0.05$ & $r=0.09 *$ & $r=-0.05$ & $r=-0.02$ \\
$p=0.20$ & $p=0.03$ & $p=0.16$ & $p=0.58$ \\
\hline \hline
\end{tabular}

${ }^{\star} \mathrm{p}<0.05 \quad{ }^{* *} \mathrm{p}<0.01$

\section{Gender differences in community attitudes towards the mentally ill}

There were no differences in years of education/years of age when male vs. female students were compared. In the General Population group, there were no differences in years of education between males and females. Males in our sample were older $(39.7 \pm 15.8)$ than females $(36.8 \pm 15.1)(\mathrm{p}=0.03, \mathrm{t}=-2.153$, $\mathrm{df}=560)$.

Female gender was associated with more favorable attitudes across all subscales, when our total sample was taken into consideration. When subgroups were analyzed, female gender was con- sistently associated with greater Benevolence, irrespective of group affiliation (General Population or Medical Students). The difference between males and females in benevolence was medium-small (according to Cohen's d values), while in all other dimensions it was negligible. The results are shown in Table 4.

\section{DISCUSSION}

To the best of our knowledge, this is the first study that assessed current state of community attitudes towards the mentally ill in Serbia. The results of the present study confirm our hypothesis, namely that medical students 
Table 4.

Gender differences in attitudes towards the mentally ill

\begin{tabular}{l|c|c|c|c|}
\multirow{2}{*}{} & \multicolumn{3}{|c|}{ Total sample } \\
\cline { 2 - 5 } & $\begin{array}{c}\text { Male } \\
(\mathrm{X} \pm \mathrm{SD})\end{array}$ & $\begin{array}{c}\text { Female } \\
(\mathrm{X} \pm \mathrm{SD})\end{array}$ & $\mathrm{p}$ & $\begin{array}{c}\text { Cohen's } \\
\mathrm{d}\end{array}$ \\
\hline Authoritarianism & $2.61 \pm 0.54$ & $2.50 \pm 0.49$ & $0.00 * *$ & 0.21 \\
\hline Benevolence & $3.83 \pm 0.60$ & $4.03 \pm 0.52$ & $0.00^{* *}$ & 0.35 \\
\hline Community psychiatry ideology & $3.65 \pm 0.61$ & $3.79 \pm 0.54$ & $0.00 * *$ & 0.24 \\
\hline Social restrictiveness & $2.48 \pm 0.60$ & $2.35 \pm 0.56$ & $0.00^{* *}$ & 0.22 \\
\hline \hline
\end{tabular}

show more favorable attitudes towards the mentally ill than general population across all dimensions. It has been consistently shown that people with adequate knowledge about mental illness (i.e. greater mental health literacy) have overall more positive attitudes towards the mentally ill ${ }^{[20,21]}$. Furthermore, generally more educated participants from the General Population were less authoritarian and had more favorable attitude towards the idea of community psychiatry. The factor of education has been highlighted in multiple studies in relation to mental illness stigma ${ }^{[22-24]}$. Interestingly, Medical Students' Authoritarian stance tended to drop with years of age, while this was not the case with the General Population sample.

When considering the examined differences between the Medical Students and General Population groups, one must note the effect of the influence of gender imbalance between the groups, i.e. more female participants in the Medical Students group. This proportion of male/female gender in our groups is an accurate representation of large medical student populations in Serbia, and has been shown in previous studies ${ }^{[25,26]}$. Female gender has been consistently associated with more compassionate approaches towards the mentally ill[ ${ }^{[24]}$.

When in-group gender differences were examined, it was shown that female medical students were more benevolent, and had a more favorable opinion towards community integration of the mentally ill than their male counterparts. Females from the general population have shown more positive attitudes across almost all dimensions, 


\begin{tabular}{|c|c|c|c|c|c|c|c|}
\multicolumn{5}{|c|}{ General population } & \multicolumn{5}{c|}{ Medical Students } \\
\hline $\begin{array}{c}\text { Male } \\
(X \pm S D)\end{array}$ & $\begin{array}{c}\text { Female } \\
(X \pm S D)\end{array}$ & $p$ & $\begin{array}{c}\text { Cohen's } \\
d\end{array}$ & $\begin{array}{c}\text { Male } \\
(X \pm S D)\end{array}$ & $\begin{array}{c}\text { Female } \\
(X \pm S D)\end{array}$ & $p$ & $\begin{array}{c}\text { Cohen's } \\
d\end{array}$ \\
\hline $2.74 \pm 0.51$ & $2.64 \pm 0.51$ & $0.04^{*}$ & 0.19 & $2.45 \pm 0.55$ & $2.40 \pm 0.48$ & 0.12 & 0.09 \\
\hline $3.67 \pm 0.62$ & $3.93 \pm 0.57$ & $0.00 * *$ & 0.43 & $3.91 \pm 0.58$ & $4.11 \pm 0.46$ & $0.00 * *$ & 0.38 \\
\hline $3.58 \pm 0.58$ & $3.67 \pm 0.53$ & 0.07 & 0.16 & $3.72 \pm 0.64$ & $3.88 \pm 0.53$ & $0.00 * *$ & 0.27 \\
\hline $2.59 \pm 0.56$ & $2.48 \pm 0.55$ & $0.03^{*}$ & 0.20 & $2.34 \pm 0.62$ & $2.25 \pm 0.55$ & 0.09 & 0.15 \\
\hline \hline
\end{tabular}

but the effect sizes in most of the gender comparisons were small, except for the benevolence.

Analysis of the attitudes from Ziropadja et al. (Montenegrin population) has shown that female gender was a significant predictor of overall favorable attitudes, which further supports our findings ${ }^{[16]}$. Furthermore, it has been shown that female gender and younger age were associated with more positive attitudes in a study assessing multiple European countries ${ }^{[27]}$.

When comparing attitudes to countries from the region, our sample has shown similar attitudes to those from the Republic of Srpska, where Niskanovic et al. ${ }^{[17]}$ included a representative sample of general population and mental health professionals. In comparing the data from our studies in Serbia and
Republic of Srpska, we observed similar scores in Benevolence (3.95 vs. 3.87, respectively) and Authoritarianism (2.55 vs. 2.58 , respectively). When translated from objective scale measures, these scores should be interpreted as attitudes inclining towards sympathetic and considerate views, and mostly disagreeing with coercive handling of psychiatric patients. However, our sample had more positive attitudes towards community psychiatry ideology (3.73 vs. 3.46 , respectively), perhaps signifying the understanding and readiness of Serbian population for the implementation of comprehensive community-based care of the mentally ill.

Comparing to the representative populations from other European countries we have shown more positive attitudes across multiple domains. Results 
from Spain yielded that CAMI scale could be considered as a comprehensible instrument for evaluating social stigma in the adolescent populations ${ }^{[28]}$. Although not directly comparable to our sample, when examined in the context of the General Population in our study (i.e. persons without exposure to specific educational interventions), we can observe somewhat similar stances in Authoritarianism (2.69 vs. 2.67 , Serbia vs. Spain, respectively), but with large differences in Benevolence (3.86 vs. 2.21 , respectively). Still, Serbian general population showed more proneness towards social restrictiveness when compared to adolescents from Spain (2.53 vs. 2.22 , respectively). It seems reasonable to hypothesize that increase in the social restrictiveness stance is at least somewhat explained by the aging population. Interestingly, it has been previously shown that as people's age increases, they believe that they have the ability to recognize a psychiatric patient just by looking at them ${ }^{[29]}$. Multiple factors are presumably at play, but nevertheless, age and specific nation-based and wider social circumstances should be taken in consideration when assessing changes in public's opinion.

When compared to mental health workers from Italy, Serbian medical students showed similar Benevolence levels (4.04 vs. 3.97, respectively), but higher Authoritarian views (2.42 vs. 2.21 , respectively ${ }^{[30]}$. Italy has been tra- ditionally considered as a nation highly sensitive to ideas of deinstitutionalization, especially since the passing of $\mathrm{Ba}$ sagla's law ${ }^{[31]}$. As mentioned previously, multiple factors could influence these differences; however the description of stigmatizing attitudes in different populations is a step towards the advancement of deinstitutionalization. Hansson et al. showed that community mental health ideology significantly improved with the rise of mental literacy associated with the national anti-stigma campaign in Sweden ${ }^{[32]}$. Furthermore, an increase of open mindedness, pro-integration and decrease of fear and avoidance in attitudes has been observed after these interventions. The authors conclude that anti-stigma campaigns involving lived experience people can have a significant positive impact on mental health literacy.

Non-European countries (Asia, Africa) had generally less favorable attitudes when compared to Serbia, across all domains, especially in rural communities ${ }^{[33,34]}$. Researchers examining these communities urge the development of strategies for enlightening the public regarding mental illness ${ }^{[34]}$. However, evidence from anti-stigma campaigns in the UK showed no significant changes, and even deterioration in public attitudes towards the mentally ill between years 2000 and $2003^{[35]}$. Authors conclude that this could be the effect of adverse media reporting during the heat- 
ed debates about the changes to mental health legislation. This further underlines the importance of dissemination of objective facts, through media or otherwise, about the nature of mental illness, thus raising mental health literacy.

The present study showed that the attitudes towards the mentally ill in Serbia seem to be similar to Western countries with progressive social outlooks. Even so, the implementation of comprehensive community care of psychiatric patients seems to be restricted. Given that the results of our study indicate multiple positive attitudes, especially in the medical students (i.e. those who received some knowledge about mental health), the next step concerning deinstitutionalization could rest in the hands of the legislators.

Deinstitutionalization has been established as a progressive societal objective, with the ultimate goal of the betterment of the mentally ill. The Law on Protection of Persons with Mental Disabilities in Serbia ${ }^{[36]}$ clearly states that "people suffering from mental disorders have the right to treatment in the least restrictive environment". The need for psychosocial rehabilitation is also noted, however the analysis of deinstitutionalization process in multiple nations showed that problems with implementing policies have been pronounced due to institutional inertia, manifested partially in long legislative proceedings ${ }^{[37]}$.

We note the limitations of our study, namely our survey did not include the assessment of experience with mentally ill. Also, precise measurement of the level of mental health literacy was not available. We have not controlled for the profession of our general population sample, just for the years of education, so the inclusion of some physicians in the general population sample (by chance) could influence the results to some extent. Furthermore, the cross-sectional design of our study disabled us from making firm conclusions on the causality of such results. However, the usage of standardized and well accepted questionnaire enabled us to identify both negative and positive aspects of the attitudes, as noted by other authors. Furthermore, by sampling two different groups (General Population and Medical Students) we were able to focus on the significance of the mental health education in Medical Students vs. General Population. Further surveys involving other groups of professionals (and future professionals) with different levels of deployment related to mental health care (psychologists, social workers, jurists and lawyers, journalists, etc.), alongside people with lived experience of mental illness, should be recommended.

\section{CONCLUSION}

Overall positive attitudes in the Serbian general public suggest that once legislative proceedings for better com- 
munity integration are initiated, we might expect identifiable improvements in community management of persons with mental health issues. The process of reform is not easy, especially in a country facing social transition. Nevertheless, focused educational interventions that include the general public should be devised, and their effect carefully and consistently evaluated. Furthering the knowledge about mental illness, and integration of the mentally ill in the community is considered essential by the authors of this article. 


\section{STAVOVI U ZAJEDNICI PREMA OSOBAMA SA DUŠEVNIM SMETNJAMA U SRBIJI}

\section{Stefan Jerotic ${ }^{1}$}

Sara Paravina ${ }^{2}$

Anđelija Nikčević ${ }^{3}$

Gordana Mandić Gajić ${ }^{3,4}$

Željko Špiric ${ }^{3,4}$

Nadja P. Marić ${ }^{1,2}$

1 Klinika za psihijatriju,

Klinički centar Srbije,

Beograd, Srbija

2 Medicinski Fakultet,

Univerzitet u Beogradu,

Beograd, Srbija

3 Medicinski Fakultet

Vojnomedicinske akademije,

Univerzitet odbrane u Beogradu,

Beograd, Srbija

4 Klinika za psihijatriju,

Vojnomedicinska akademija,

Beograd, Srbija

UDK: 616.89-008.47:617.7

doi: $10.5937 /$ engrami1902050J

\section{Kratki sadržaj}

Uvod. Uključivanje i integracija osoba sa psihičkim smetnjama u zajednicu predstavlja jedan od osnovnih ciljeva unapređenja zaštite duševnog zdravlja i društvene rehabilitacije. Ključan koncept u reformi sistema mentalnog zdravlja, kada su u pitanju zemlje zapadnog sveta, podrazumeva deinstitucionalizaciju. Imajući navedeno u vidu, uspeh strategija za implementaciju deinstitucionalizacije u značajnoj meri zavisi od stavova opšte populacije prema osobama sa duševnim smetnjama. Takođe, studenti medicinskog fakulteta tokom svog obrazovanja stiču određena znanja o problemima mentalnog zdravlja. Oni, kao budući profesionalci, učestvuju u stvaranju i prenošenju stavova u zajednicu o osobama sa psihičkim smetnjama.

Cilj. Ispitivanje stavova u zajednici prema osobama sa duševnim smetnja- 
ma $\mathrm{u}$ reprezentativnom uzorku opšte populacije i kod studenata dva medicinska fakulteta u Srbiji.

Metod. Ova studija preseka je obuhvatila 1068 ispitanika: 562 studenta medicinskog fakulteta i 506 subjekata iz opšte populacije. Ispitivanje stavova je izrvšeno primenom instrumenta "Stavovi u zajednici prema osobama sa duševnim smetnjama" ("Community attitudes towards the mentally ill”). Četiri dimenzije stavova, izvedenih iz skale, su analizirani: autoritaronost, blagonaklonost, socijalna ograničenja i odnos prema ideji mentalnog zdravlja u zajednici.

Rezultati. Studenti medicine su imali povoljnije stavove u odnosu na opštu populaciju na svim dimenzijama skale. U opštoj populaciji, niži broj godina obrazovanja je bio povezan sa višim nivoima autoritarnih stavova. Nezavisno od grupe, ženski pol je bio dosledno povezivan sa višim nivoima blagonaklonosti.

Zaključak. Sveukupno, prisutni su pozitivni stavovi u zajednici prema osobama sa duševnim smetnjama u Srbiji. Ovaj nalaz sugeriše da, u trenutku pokretanja legislative za bolju integraciju osoba sa duševnim smetnjama u širu zajednicu, možemo očekivati brze i značajne rezultate usled društveno povoljnih okolnosti.

\section{Ključne reči:}

deinstitucionalizacija, društvena stigma, autoritarnost, blagonaklonost

\section{LITERATURE / LITERATURA}

1. Killaspy H. From the asylum to community care: Learning from experience. Br Med Bull 2006;7980:245-58. doi:10.1093/bmb/ldl017.

2. Priebe $S$, Badesconyi $A$, Fioritti $A$, Hansson L, Kilian R, Torres-Gonzales F, et al. Reinstitutionalisation in mental health care: Comparison of data on service provision from six European countries. Br Med J 2005;330:123-6. doi:10.1136/bmj.38296.611215.AE.

3. Becker T, Vazquez-Barquero JL. The European perspective of psychiatric reform. Acta Psychiatr Scand 2001;104:8-14. doi:10.1034/j.16000447.2001.1040s2008.x.

4. Fakhoury W, Priebe S. The process of deinstitutionalization: An international overview. Curr Opin Psychiatry 2002;15:187-92. doi:10.1097/00001504-20020300000011.

5. Lecic Tosevski D, Pejovic Milovancevic M, Popovic Deusic S. Reform of mental health care in Serbia: ten steps plus one. World Psychiatry 2007;6:115-7.

6. Ministry of Health of the Republic of Serbia. Strategy for the Development of Mental Health Care. 2007.

7. Tosevski DL, Gajic SD, Milovancevic MP. Mental healthcare in Serbia. Int Psychiatry 2010;7:13-5.

8. van Weeghel J, van Audenhove C, Colucci M, Garanis-Papadatos T, Liégeois A, McCulloch A, et al. The components of good community care for people with severe mental illnesses: views of stakeholders in five European countries. Psychiatr Rehabil J 2005;28:274-81. 
doi:10.2975/28.2005.274.281.

9. ten Have M, de Graaf R, Ormel J, Vilagut G, Kovess V, Alonso J, et al. Are attitudes towards mental health help-seeking associated with service use? Results from the European Study of Epidemiology of Mental Disorders. Soc Psychiatry Psychiatr Epidemiol 2010;45:153-63.

10. Taylor SM, Dear MJ. Scaling community attitudes toward the mentally ill. Schizophr Bull 1981;7:225-40. doi:10.1093/ schbul/7.2.225.

11. Sévigny R, Yang W, Peiyan Z, Marleau JD, Zhouyun Y, Lin S, et al. Attitudes Toward the Mentally Ill in a Sample of Professionals Working in a Psychiatric Hospital in Beijing (China). Int J Soc Psychiatry 1999;45:41-55.

12. Morris R, Scott PA, Cocoman A, Chambers $M$, Guise V, Välimäki $M$, et al. Is the Community Attitudes towards the Mentally Ill scale valid for use in the investigation of European nurses' attitudes towards the mentally ill? A confirmatory factor analytic approach. J Adv Nurs 2012;68:460-70. doi:10.1111/j.13652648.2011.05739.x.

13. Winkler $P$, Mlada K, Janouskova $M$, Weissova A, Tuskova E, Csemy L, et al. Attitudes towards the people with mental illness: comparison between Czech medical doctors and general population. Soc Psychiatry Psychiatr Epidemiol 2016;51:1265-73. doi:10.1007/s00127-016-1263-y.

14. Angermeyer MC, Dietrich S. Public beliefs about and attitudes towards people with mental illness: A review of population studies. Acta Psychiatr
Scand 2006;113:163-79. doi:10.1111/ j.1600-0447.2005.00699.x.

15. Song L-Y, Chang L-Y, Shih C-Y, Lin C-Y, Yang M-J. Community attitudes towards the mentally ill: the results of a national survey of the Taiwanese population. Int J Soc Psychiatry 2005;51:162-76. doi:10.1177/0020764005056765.

16. Žiropaa L, Dulović A. Attitudes Towards Mentally Ill In Montenegro: The Montenegrin Version Of CAMI. Engrami 2014;36:27-38.

17. Niškanović J, Šiljak S. Stigma prema mentalnom poremećaju meu opštom populacijom i zdravstvenim radnicima službe porodične medicine. [Stigma toward people with mental disorders among general population and health professionals of family medicine.]. Psihijatr Danas 2013;45:125-37.

18. Rosenthal R. Parametric measures of effect size. Handb. Res. Synth., 1994, p. 231-44.

19. Statistical Office of the Republic of Serbia. Census of Population, Households and Dwellings in the Republic of Serbia 2011.

20. Chiles C, Stefanovics E, Rosenheck R. Attitudes of Students at a US Medical School Toward Mental Illness and Its Causes. Acad Psychiatry 2017;41:3205. doi:10.1007/s40596-016-0508-0.

21. Jorm AF. Mental health literacy: Empowering the community to take action for better mental health. Am Psychol 2012;67:231-43. doi:10.1037/ a0025957.

22. Gonzalez JM, Alegria M, Prihoda TJ. How do attitudes toward mental health treatment vary by age, gender, and ethnicity/race in young adults? J 
Community Psychol 2005;33:611-29. doi:10.1002/jcop.20071.

23. Corrigan PW, Morris SB, Michaels PJ, Rafacz JD, Rüsch N. Challenging the Public Stigma of Mental Illness: A Meta-Analysis of Outcome Studies. Psychiatr Serv 2012;63:963-73. doi:10.1176/appi.ps.201100529.

24. Corrigan PW, Watson AC. The stigma of psychiatric disorders and the gender, ethnicity, and education of the perceiver. Community Ment Health J 2007;43:439-58. doi:10.1007/s10597007-9084-9.

25. Totic S, Stojiljković D, Pavlovic Z, Zaric N, Zarkovic B, Malic L, et al. Stigmatization of 'psychiatric label' by medical and non-medical students. Int J Soc Psychiatry 2012;58:455-62. doi:10.1177/0020764011408542.

26. Marusic V, Markovic-Denic L, Djuric O, Protic D, Dubljanin-Raspopovic E. Knowledge about blood-borne pathogens and the prevalence of needle stick injuries among medical students in Serbia. Zdr Varst Mental Illness. Rev Psiquiatr y Salud
Ment (English Ed 2016;9:150-7. doi:10.1016/j.rpsmen.2015.02.002.

29. Vezzoli R, Archiati L, Buizza C, Pasqualetti P, Rossi G, Pioli R. Attitude towards psychiatric patients: A pilot study in a northern Italian town. Eur Psychiatry 2001;16:451-8. doi:10.1016/S0924-9338(01)00606-X.

30. Chambers M, Guise V, Välimäki M, Botelho MAR, Scott A, Staniuliené $V$, et al. Nurses' attitudes to mental illness: A comparison of a sample of nurses from five European countries. Int J Nurs Stud 2010;47:350-62. doi:10.1016/j.jinurstu.2009.08.008.

31. Scheper-Hughes N, Lovell AM. Breaking the circuit of social control: Lessons in public psychiatry from Italy and Franco Basaglia. Soc Sci Med 1986;23:159-78. doi:10.1016/02779536(86)90364-3.

32. Hansson L, Stjernswärd S, Svensson B. Changes in attitudes, intended behaviour, and mental health literacy in the Swedish population 20092014: an evaluation of a national antistigma programme. Acta Psychiatr Scand 2016;134:71-9. doi:10.1111/ acps.12609.

33. Barke A, Nyarko S, Klecha D. The stigma of mental illness in Southern Ghana: Attitudes of the urban population and patients' views. Soc Psychiatry Psychiatr Epidemiol 2011;46:1191-202. doi:10.1007/ s00127-010-0290-3.

34. Vijayalakshmi R, Nagarajaiah P, Reddenna K, Math SB. Attitude and response of a rural population regarding person with mental illness. Dysphrenia 2013;4:42-8.

35. Mehta N, Kassam A, Leese M, Butler 
G, Thornicroft G. Public attitudes

towards people with mental illness

in England and Scotland, 1994-2003.

Br J Psychiatry 2009;194:278-84.

doi:10.1192/bjp.bp.108.052654.

36. Serbia R of. Law on the Protection of Persons with Mental Disorders. Off Gazzete RS 2013;45.

37. Shen GC, Snowden LR. Institutionalization of deinstitutionalization: A crossnational analysis of mental health system reform. Int J Ment Health Syst 2014;8. doi:10.1186/1752-4458-8-47.

Stefan Jerotić

Clinic for Psychiatry, Clinical Center of Serbia

Pasterova 2, 11000 Belgrade, Serbia

stefan.jerotic@gmail.com 